\title{
THE ECONOMIC DEVELOPMENT OF JAPAN
}

$\operatorname{AUTHOR}(\mathrm{S})$ :

Honjo, Eijiro

CITATION:

Honjo, Eijiro. THE ECONOMIC DEVELOPMENT OF JAPAN. Kyoto

University Economic Review 1931, 6(1): 14-28

ISSUE DATE:

1931-07

URL:

https://doi.org/10.11179/ker1926.6.14

RIGHT: 


\title{
Kyoto University \\ Economic Review
}

\author{
MEMOIRS OF \\ THE DEPARTMENT OF ECONOMICS
}

IN

THE IMPERIAL UNIVERSITY OF KYOTO

VOLUME VI

1931 
THE ECONOMIC DEVELOPMENT

OF JAPAN

\section{FROM SELF-SUFFICIENT ECONOMY TO LOCAL ECONOMY}

In the ancient time when the shizoku system prevailed, the solidarity of society was based upon blood relationship. The principal means of production at that time were land and labour both of which belonged to each $u j i$ (or gens) which ruled over the subject groups of be and yakko, the latter people being engaged in manual labour. The people of that time had already passed the period of hunting and fishery and had entered that of agriculture. Thus, it was clear that they lived in an era of land economy.

Each $u j i$ at that time was engaged in a particular occupation at the head of the people of the $b e$ who were occupied in manual labour. The people of the $b e$ were asso engaged in agriculture and fishery in addition to the particular occupation of each $b e$, and thus earned the necessaries of their daily life. Such must have been their ordinary mode of existence. One would, therefore, be jumping at a conclusion should he venture to judge from the existence of different occupations that there was a systematic division of labour among the inhabitants it ancient times. Nor is it certain that each $u j i$ lived a communistic life by itself as a whole. As time passed, all the members of the same $u j i$ no longer lived in the same place; they lived in different places. (An example of this may be found in the fact that the Imbe $U j i$ was different in the provinces of Kii, Awa, Sanuki and Tsukushi). It is impossible to conceive that by the time the $u j i$ system was at the height of its development; an individual $u j i$ constituted an economic unit. On the contrary, the family 
was the economic unit, all the members of family being occupied in its work under the direction of its head. In some cases, bodies somewhat larger than the family-a group of families or of members of a $b e$-were probably engaged in self-sufficient economy as an economic unit. In some exceptional cases, a small $u j i$ might have been an economic unit, but, generally speaking, it was the family that formed the foundation of economy. In short, the economic order of ancient times in Japan was one of land economy based upon gentilitial or clan relations. In principle, it was an economy of self-sufficiency, with the family as the economic unit and the association of the be as the centre of the labor system. The $u j i$ greatly contributed towards the development of agriculture and of other industrial arts by employing the members of a family, and, more particularly, the people of the $b e$, in the development of land and other manual labour. However, there is another important factor that should not be lost sight of and that is the influence of foreign culture and Buddhism upon the progress of the economy of the time.

Intercourse between Japan and Korea was carried on from early times in the history of this country. Japan freely imported culture from Korea, especially after the Korean principalities became subjected to her. Many Koreans became naturalized in Japan. Some of them brought with them such industrial technologies as sericulture, weaving, ceramics, carpentry and leather manufacturing, while others imported gold, silver, jewels and textiles. Buddhism found its way into Japan during the reign of the Emperor Kimmei (540572 A.D.) and its spread greatly affected not only the religious faith of the people, but also the nation's economic and social life; its effects upon architecture, sculpture, and industrial arts were at once direct and profound. It is clear that the changes brought about by foreign relations and the introduction of Buddhism, coupled with the industrial policy of the period, contributed greatly towards the economic development of the country. 
With the lapse of time, the population of the country increased and territorial relations came to play a more important rôle than blood relationship. After the Taikwa Reform abolished the government by $u j i$ and created a centralised government in its place, the $u j i$ ceased to have great importance. The provisions of the Taiho Law deals with the $k o$ or family but not with the uji. Thus, the political and legal unit had shifted from the $u j i$ to the $k o$. In the world of economy, the ownership of land shifted from the $u j i$ to the Emperor, as the result of the distribution of land under the handen system; the right of using land and deriving profits therefrom also shifted from the $u j i$ to the $k o$ whose position as an economic unit became more clearly established than in former times. The necessity of supplementing the labor power of the members of families made the labour power of slaves increasingly important. In short, the $k o$ or the big family system functioned as an economic unit. Both shrine and temple could be regarded as a family which lived a self-sufficient economic life and was engaged in land economy.

Foreign culture and Buddhism also exercised much influence on the economic development of this time. But no less important were the use of slave labour and the distribution of land under the handen system, both of which were the important features of the time. The majority of slaves were employed in productive work, men being engaged in agriculture and women in sericulture and weaving. Some were employed in industrial and domestic work. I have already explained the handen system in a previous issue of this journal ${ }^{1)}$. The disintegration of the handen system set in when the scarcity of fields came to be felt with the rapid increase in the population. Encouragement of the development of new fields by private hands became inevitable and this resulted in the break-up of the public ownership of

I) A Short History of Social Problems in Japan before the Restoration, in this Review, Vol. III, No. 2. 
land, in the development of private fields and in the formation of the shoen.

The next period was marked by the phenomenal development of the shöen system. In each shōen there was a "shoke" or residence of its lord or his representative, and was inhabited by persons who tilled the soil and produced all necessaries of daily life. A shöen was also inhabited by persons having no fixed domicile and who were employed by the lord of the shoen or by other wealthy landlords. The shoen, in short, formed an individual economic area. There is reason to believe that a self-sufficient economy was carried on also in a shōen. The shöke was not necessarily located at the geographical centre of a shöen. However, the life of a shöen must have been carried on with the shōke as its centre. This may be seen in the fact that the governance of a shōen was directed by the shōke, and that taxes in kind were first conveyed to the shöke or to a warehouse usually situated nearby and then properly distributed afterwards. But at that time, it appears that money came to be coined and used especially in cities; the appearance of these cities being also a phenomenon of the times. In and around the capital and other important points, the old self-sufficient economy faced changes.

Thus, although in principle the economic order of the old centralized government was self-sufficiency, currency became increasingly used and the people lived a currency life to a certain degree. After political power passed into the hands of the warrior class in the middle ages, a rapid advance was made in this respect; a handicraft industry was devoloped, cities expanded, commercial transactions were carried on more and more extensively and commission merchants and exchange business also made their appearance. Although the coining of money was discontinued for some time, currencies of small denominations, (chiefly Chinese coins) were used quite extensively. Trade was carried on with countries beyond the seas, and communication with overseas countries was carried on with increasing vigour. 
These economic phenomena indicate that the people of the time were not satisfied with the old time domestic economy or shoen economy and that they had expanded local economic area and developed currency economy to a certain extent. However, they continuously held land as the centre and agriculture as the foundation, of their economic life. In other words, while in ancient times agriculture was the only industry, in the middle ages besides agriculture there were also industry and commerce; and the classes of artisans and tradesmen came into existence. True, the great majority of the people still were engaged in agriculture and tradesmen and artisans followed their vocations under the protection of the Imperial Court, the aristocracy, shrines and temples. At any rate, one may say that commerce and industry had definitely come to be distinct vocations.

I have already dwelt on the close relations between ancient economy and Buddhism. Now, there were similar relations between shrines and temples on the one hand and economy on the other in the middle ages. There are many facts showing that the development of industry was made under the ægis of religious establishments. The development of lands, the introduction of special agricultural products (such as tea, for example), the development of architecture and sculpture, the holding of commercial fairs in front of some shrine or temple and on the days of their festivals, and the manufacture and sale of medicines and other products-these will be sufficient to show the close relations between the industrial development of the middle ages and shrines and temples. There is no doubt that the formation of monzen-machi (streets in front of temples and shrines) in all parts of the country was the natural result of the religious establishments, which were the only places of safety during the middle ages, a period marked by civil disturbances. As I have already pointed out elsewhere ${ }^{2)}$, people carried on business under the protection of shrines and temples. Some

2) ibid. 
entrusted their precious documents and treasures to these sacred places in order to protect them from the destruction and pillage of warfare. Shrines and temples also acted as financial organs and made loans; made co-operative credit facilities known by the names of "mujin" and "tanomoshi"; and utilised bills of exchange. Thus, the position of shrines and temples in the financial mechanism of the country was very important. In the communications of the time, the establishment of barriers known as "sekisho" during the middle ages also had close relations with shrines and temples.

\section{FEUDAL ECONOMY OF EXCLUSION IN MODERN TIMES}

Each han or feudal clan during the Tokugawa Period enjoyed comparative autonomy, carried on a self-sufficient economy within its walls, different clans having different systems of currency as well as other systems of their own. But the period did not have a purely local economy as did the former times; its economy had gradually assumed a national character, due to the political unification of the entire realm. The continued maintenance of peace led to the development of the business world and the expansion of markets. It was not an uncommon event, even as early as the Jōkyö Era (1684-1688) and the Genroku Era (16881704), that the sea products of the northern part of the country should be sold at Edo, the seat of the Feudal Government, and the merchants of the northern clans carried on business transactions in Kyoto, the ancient capital in the central part of the country. The silk textile called "Nishijinori" was in great demand by the feudal princes throughout the entire realm. The sake produced in the towns of Ikeda, Itami, and Nada was first conveyed to Bakwan, the chief point for the reception and distribution of freights for Kyūshu and the northern provinces and then shipped to the territories along the coast of the Japan Sea and in Kyūshu. The same national beverage was also shipped to Edo to be used 
by its inhabitants and not a few commission merchants there amassed a fortune. The oil made from rape-seed, a plant very extensively raised in the central part of Japan, was shipped to Edo and other important points. Such products as the bleached textile of Nara, cotton cloths of Kawachi, candles of Aizu, bears' gall produced in Kaga and Etchu, salted yellow-tail of Tango, seaweeds of Matsumae-these were all first sent to the three great cities of Edo, Osaka, and Kyoto and then distributed in different parts of the country. It was the city of Osaka which was the centre of commercial activities at that time. Feudal princes had their warehouses in Osaka to which they sent their native products to be sold. There was a regular freight service between Edo and Osaka thereby facilitating the transportation of the products of Osaka and nearby provinces to the Kanto or Eastern Japan. The products of all provinces were first assembled at Osaka and then were distributed to all parts of the country by various routes. Cognisance should be taken of the fact that the merchants of Ohmi and the drug peddlers of Toyama travelled throughout the entire country. Industrial arts such as lacquer and drapery were transplanted in the Kanto district from Kyoto. The development of communications and of exchange business between Edo and Osaka indicates that the economic relations of the period were not locally isolated but had close connection among themselves. Thus, the economic system of our country advanced from local to national, especially after the middle of the Tokugawa Period. However, when seen from an external standpoint, the period was an era of exclusion which was more and more strictly enforced as time passed. There were various restrictions in economic matters and no progress was made in the nation's foreign trade. Moreover, the foreign trade of the time was one-sidedly in favour of imports, so that the production of commodities within the country was made with the demand in the domestic market as the standard; and the so-called circulation of goods was strictly domestic in character. This is why the Tokugawa 
Period may be called an era of economic exclusion.

The chief feature of society during the Tokugawa Period was the existence of feudal classes and this feudal characteristic was often seen in the world of economy. For instance, there was a guild system called "kabunakama" under which persons engaged in the same occupation had certain privileges ; each clan issued its own notes for monetary purposes ; the road and the communication policy also showed the earmarks of feudalism. Under this feudal system there was a long period of peace seldom seen in the history of mankind, thereby enabling the people to pursue their respective vocations while the government authorities directed their efforts toward the development of industries; the result was that, although no expansion was made in the nation's foreign trade, various industries were developed in all parts of the nation. We may, therefore, say that our country received the benefits of protected trade by means of a policy of national exclusion.

The Tokugawa Period is known as "an era of rice economy", because its finance and economy were based upon rice. However, the use of money as the medium of exchange was extensively developed during this period. True, it cannot be said to be a pure currency economy such as now exists; but the extension of the use of money could never be compared with those in the previous periods. Hitherto, land had been considered as the only form of wealth, but now gold and silver also came to be regarded as important forms of wealth; and although an ideological discrimination was made against money in favour of rice, the former, in reality, was highly prized and it was extensively used in cities as well as rural districts. This meant a shift from land economy to money economy.

Agriculture was the most important industry in Japan from the earliest known times and remained the centre of her industrial life during the Tokugawa Period. However, there emerged during this same period two other industries, namely, commerce and manufacturing, and this accompanied 
the rise of the chonin (commoner) class and the growth of cities. At that time both the Feudal Government and the daimyos suffered much because of financial difficulties. Accordingly, they tried to meet the situation by developing new rice fields for the purpose of increasing their annual rice revenue, by encouraging industrial activities, by establishing something like monopolies, by re-coining money and issuing clan notes, and more generally by imposing heavy taxes on farmers. But since there was a natural limit to the capacity of these people to bear the tax burden, the Feudal Government and daimyos borrowed money from the wealthy merchants of Edo and Osaka. They did not hesitate to bow before the commoners in securing the needed money, and tried profitably to arrange their finances with the latter's financial assistance. The Chonin-bukuro says: "The entire realm has become the consumer of gold and silver, the change having started almost imperceptibly. Now, gold and silver being largely under the control of the chonin, they were often called into the presence of nobles, and their social position seemed to rise above that of farmers." In reality, the new mercantile class surpassed, not only farmers, but even samurai in point of real power. The chonin held the power of money and occupied an influential position in society. Kunpei Gamo is said to have declared that the ire of Osaka's rich merchants would prove a terror for the feudal princes of the land. His words are sufficient to indicate the real power of the commoners of the period.

With the development of currency economy and the rise of the chonin class, the members of other classes also tried to adapt themselves to the changed social conditions, took part in the obtaining of economic interests, and became more and more like merchants. I have already stated that shrines and temples were engaged in lucrative undertakings in the middle ages; the same was true during the Tokugawa Period. Some temples produced particular commodities and sold them; others carried on the business of money-lending. The Myōshin-ji in Kyoto, the Kan-ei-ji and the Zō-jō-ji in Edo 
were particularly notable in this respect. Some temples even managed the tomitsuki, a sort of lottery which took advantage of people's speculative spirit. Teachers of the arts and music charged special tuition and other fees. Blind money lenders charged outrageously high rates as they enjoyed a special privilege as money lenders. The fact that each daimyo established industrial monopolies within his own territory shows the extent of the commercialisation of the feudal princes. In short, the power of money came to replace the power of military force.

Under the feudal system of that time, land was the principal means of production, farmers were the oniy productive class, a privileged class composed of samurai was supported by the labor of the former class. Unlike those of the Kamakura Period, the samurai of the Tokugawa Period were detached from the land, were unproductive as a class and were supported by the farming class. With the continuation of peace, the people's standard of living was raised, their habits of luxury increased and the financial expenditure of governing the country was expanded, the result being that both the Feudal Government and the daimyos were unable to make both ends meet and became extremely impoverished. For a long time the agricultural policy of the feudal and clan governments was dictated by the idea "that farmers should pay taxes to the degree that they might neither die nor live "-the idea being that farmers should be allowed to retain just sufficient of their agricultural products to make a bare rustenance. As time passed, however, the tax burden of farmers became heavier and heavier and their living conditions were subjected to untold diffculties. In order to escape this hard lot, farmers tried to leave their farms for the city, or carry on trade on a small scale in the country, or exercise a crude system of birth control called "mabiki". All these resulted in a scarcity of labor power in the rural districts; farms became desolate and the gap between the rich and poor in agricultural villages more pronounced. Rioting by farmers of the time was their 
positive method of breaking this deadlock in their daily life. The impoverishment and desolation of farming villages were the indication of the fact that agricultural economic power had come to an utter cul de sac, and that in consequence it became no longer able to support the samurai class and maintain the feudal system in general. On the other hand, there arose besides agriculture (which had long been regarded as the only productive means in the realm) trade and industry, with the consequent development of cities and the chonin class. Thus, it is to be noted that a new economic power made its emergence to stand side by side with the decayed agricultural power. The replacement of land economy by currency economy and the appearance of commercial capital testified to the impossibility of maintaining the feudal system founded upon land economy.

There were now mainly three social classes, samurai, farmers and chōnin. Many farmers left their farms for the cities where they became tradesmen or hired men. Samurai were also hard pressed by economic difficulties and had to pursue material gains by domestic industry or by by-works. Some of them married the daughters of merchants for the purpose of material benefits or adopted sons of chonin for similar purposes. The status of the hatamoto or of the ordinary samurai was freely sold, especially after the Kyōhō Era, and their values were fixed. Thus, chōnin smuggled themselves, as it were, into the samurai class; received fiefs by advancing loans to samurai; were allowed to have surnames and wear swords and otherwise receive the treatment of the warrior class. They also purchased land or developed new lands, thereby becoming landlords in rural districts. Thus, the chonin class overwhelmed both the samurai and the farmer classes by their sheer economic power, and there was no clear distinction among the different classes. With the economic change above described, each social class lost its characteristics and confusion was created among them. It was evident that the maintenance of the feudal system which 
was based upon class distinction was no longer possible."

We may say then that the changes brought about in the economic and social aspects of the Tokugawa Period unmistakably pointed out the inevitable collapse of the feudal system of the period.

Towards the close of the Tokugawa Period, there were indications of a great economic transformation." In the north, Russia's advance alarmed the nation, while in the south the arrival of the "blackships" struck a terror into the hearts of the people. Important economic and political changes resulted from the development of the diplomatic relations of the country, especially after the years of Kaei and Ansei. Policies which were absolutely at variance with the traditional policies of the Feudal Government were adopted, and there were signs on every hand that further changes in the social and economic conditions of the nation were inevitable. To give a few examples, the Feudal Government in reality abandoned its traditional policy of national seclusion and isolation and carried on trade activities with Western countries. New machines as well as new technologies were imported from the West and trade establishments similar to companies were founded; paper money was issued; and drastic changes were made in the system of sankin kotai which was one of the sources of financial embarrassment for local feudal princes. All of these novel measures, however, were entered upon rather as experiments and never were carried out universally. Then the battles of Toba-Fushimi laid the Edo Government prostrate. Both the Central Government and the advanced feudal clans realised that the old policies would not work and that a revolutionary change of policies was absolutely necessary. The various economic and financial policies adopted after the Imperial restoration corresponded to those already initiated during the close of

3) See my essay "Changes of Social Classes during the Tokugawa Period" in this Review Vol. III, No. 1.

4) See my essay "The New Economic Policy in the Closing Days of the Tokugawa Shogunate" in this Review Vol. IV, No. 2. 
the Tokugawa Period; it is wrong to suppose that the main policies of the Meiji Government were adopted for the first time after the overthrow of the feudal system.

\section{CAPITALIST ECONOMY AFTER THE IMPERIAL RESTORATION}

It was during the Genroku Era that currency economy began to replace natural economy. While the chief source of the Feudal Government's revenue consisted in the natural products of land, the new form of wealth, that is to say, money was concentrated in the hands of the chonin; and with the growth of currency economy, the military power of the samurai was gradually superseded and finally replaced by the monetary power of the chonin. The samurai of the Chōshu and other clans who took the prominent part in the restoration of the Imperial régime succeeded in their gigantic task by utilising the wealth of the mercantile class. The campaign funds of the battles that overthrew the feudal régime and the contributions made to the Meiji Government came from the coffers of the wealthy merchants of Osaka. It was generally believed at that time that 70 percent of the entire national wealth was concentrated in Osaka, and the founders of the Meiji Government sagaciously invited the wealthy merchants of this commercial metropolis to take sides with them in the great political struggle. Had they failed to do this, the establishment of the Meiji Government would have been wellnigh impossible.

As has already been stated, the real power of society during the later Tokugawa Period was held by the chonin class and the feudal system was bound to disintegrate. However, the power of the chonin class could not be developed beyond the fixed limit due to the feudal system and the policy of national exclusion, and it was the samurai of the lower strata of the warrior class that carried on the work of political transformation in their anti-foreign agitation as well as in their political movements for the overthrow of. 
the Edo Government. These samurai of lower station had been discontented because their rise in social status was very difficult under the then existing feudal system. They had long felt the need of making a drastic change in the system, and finally came to establish the Meiji Government. True, behind their political movement lay the awakening of the people as a whole and the financial support of the chomin class. Moreover, the general tendency of the people was towards such a political and social transformation. However, it was these samurai of the lower ranks that carried out the actual work of political revolution and after the establishment of the Modern Government became either bureaucratic administrators or leaders of the new economic system of capitalism. The members of the chonin class only followed the lead of these samurai; they always assumed a passive attitude in the historic political and social movements that culminated in the overthrow of Japanese feudalism.

Although the feudal system of the Tokugawa Period was bound to collapse when considered from the social and economic standpoints, yet the downfall of that system was not actually brought about by the chonnin class which held the real economic power of society. It was overthrown by the samurai who took advantage of the pressing diplomatic relations of the period. It is also to be noted that the samurai class had already become more and more like commoners. Economically viewed, land economy on which feudalism was based was replaced by currency economy, and the nation was forced to open its doors at the invitation of foreign capitalism.

During the Tokugawa Period in which Japan enforced a policy of national isolation and exclusion, the Western world was marked by a great material advance, consequent upon the various scientific inventions and discoveries and their utilisation in the means of communications and transportation. In other words, the West passed the period of industrial revolution, while our country lived a self-sufficient economic life within its walls; and she opened her doors in an era of 
machines and steam power. The Feudal Government and the clans imported western civilisation towards the close of the Tokugawa Period, and it was quite natural that this borrowing of western systems of political, industrial and social life should be greatly accelerated after the creation of the Meiji Government. During the first ten years of the new régime, the economic conditions of the country were in a state of confusion, due to the break-up of the old system. However, the abolition of class distinctions, the emancipation of people from various feudal restrictions, opportunity offered to men of ability without discrimination, the formation of a unified state, the establishment of monopolies, the encouragement and support of civilian enterprises, the government's direct interference and protection in industry, and the development of companies and corporations-all these prepared the way for the rise of capitalism. In the next ten years, the foundations of the new economy were firmly laid. It made immense progress after the wars with China and Russia and the modern industrial system came to control our economy. This rapid adoption of foreign capitalism was possible because of the fact that currency economy has been developed during the Tokugawa Period and thus our economy was in a position where it could be turned into capitalism. In other words, the germs of capitalism could be found in the economic order of the Feudal Period. Although some features of feudalism still persisted in remaining in the nation's economy, the so-called capitalistic society made its appearance during the Meiji Era. Japan made an abnormal economic development because of the World War and the defects in her traditional economic system were afterward disclosed, resulting in the present movement for its rationalisation and improvement.

EIJIRO HoNJo 